\title{
Taxonomic remarks on the genus Caspicosa Ponomarev, 2007 (Aranei: Lycosidae)
}

\section{Таксономические заметки о роде Caspicosa Ponomarev, 2007 (Aranei: Lycosidae)}

\section{Sergei L. Esyunin ${ }^{1 *}$, Semyon V. Vlasov ${ }^{1}$, Aleksandr V. Ponomarev ${ }^{2}$

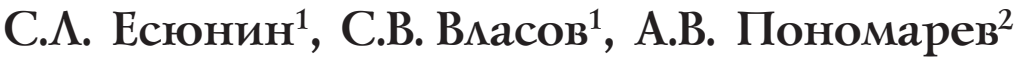

\author{
${ }^{1}$ Perm State University, Bukireva Street 15, Perm 614600, Russia. E-mail: Sergei.Esyunin@psu.ru \\ Пермский государственный университет, ул. Букирева 15, Пермь 614600 Россия. \\ ${ }^{2}$ Federal Research Centre the Southern Scientific Centre of the Russian Academy of Sciences, Chekhov Street 41, Rostov-on-Don 344006, \\ Russia. Email: ponomarev1952@mail.ru. \\ Федеральный исследовательский центр Южный научный центр РАН, пр. Чехова, 41, Ростов-на-Дону 344006, Россия \\ * Corresponding author
}

KEY WORDS: Araneae, diagnosis, review, new combination, wolf spiders.

КЛЮЧЕВЫЕ СЛОВА: Araneae, диагноз, обзор, новая комбинация, пауки-волки.

ABSTRACT. A refined diagnosis and redescription of the genus Caspicosa Ponomarev, 2007 is given, with new taxonomic and faunistic data for three species. Caspicosa manytchensis Ponomarev, 2007 (the type species) and C. kulsaryensis Ponomarev, 2007 are redescribed and illustrated on the basis of the type and newly collected materials. A new combination is proposed: Caspicosa chahraka (Roewer, 1960) comb.n. (ex Pardosa). Distribution of all species is mapped.

How to cite this article: Esyunin S.L., Vlasov S.V., Ponomarev A.V. 2020. Taxonomic remarks on the genus Caspicosa Ponomarev, 2007 (Aranei: Lycosidae) // Arthropoda Selecta. Vol.29. No.2. P.273-282. doi: 10.15298/arthsel. 29.2.14

РЕЗЮМЕ. Даётся уточненный диагноз и переописание рода Caspicosa Ponomarev, 2007, с новыми таксономическими и фаунистическими данными для трех видов. Caspicosa manytchensis Ponomarev, 2007 (типовой вид) и C. kulsaryensis Ponomarev, 2007 переписаны и проиллюстрированы на основе типовых и вновь собранных материалов. Предлагается новая комбинация: Caspicosa chahraka (Roewer, 1960) comb.n. (бывшая Pardosa). Распространение всех видов картировано.

\section{Introduction}

The genus Caspicosa Ponomarev, 2007 was established for two wolf spider species described from the Ciscaucasia (C. manytchensis Ponomarev, 2007) and the northeast Ciscaspian region (C. kulsaryensis Ponomarev, 2007) [Ponomarev, 2007]. In the original description, the author noted that Caspicosa species differ from those of Acantholycosa Dahl, 1908 in having a fewer number of the bristles on tibia I and II, and from species of Pardosa C. L. Koch, 1847 in having a very large process of palea in the male palp [Ponomarev, 2007].

To date, C. kulsaryensis has not been recorded from outside the type locality, whereas $C$. manytchensis is widespread across semiarid landscapes of the Russian Plain [Alekseenko, Kuz'min, 2010; Ponomarev, Khnykin, 2013; Ponomarev, Prishutova, 2017; Ponomarev et al., 2017a, b, 2018; Ponomarev, Alekseev, 2018]. As a result of studying the wolf spider fauna of Orenburg Region, we have found out that the latter species is also common in the steppe Cis-Urals. Another species with the characteristics of the genus Caspicosa - Pardosa chahraka Roewer, 1960 - was discovered by assessing the wolf spider fauna of Central Asia. The latter species remains known from the female only [Roewer, 1960].

The aims of the present study are (1) provide an updated diagnosis, definition and description of Caspi$\cos a$, and (2) to propose a new combination.

\section{Material and methods}

The studied material is deposited in the Zoological Museum of the Moscow State University (ZMMU, curator: K.G. Mikhailov), the Manchester Museum, University of Manchester, UK (MMUE, curator: D.V. Logunov), the Department of Invertebrate Zoology and Aquatic Ecology of the Perm State University (PSU, curator: S.L. Esyunin) and A.V. Ponomarev's personal collection (PC). Photographs were produced by using a camera SONY NEX-C3 attached to a MIKMED-6 optical microscope at the Southern Scientific Centre of the Russian Academy of Sciences (Rostov-on-Don, Russia). SEM micrographs were made by means of a Hitachi TM3000 SEM microscope with BSE (back-scattered electrons) at the Perm State University (Perm, Russia) and a Carl Zeiss EVO 40 XVP SEM microscope at the Center for Collective Usage 
Joint Centre of scientific and technological equipment of SSC RAS (Rostov-on-Don, Russia).

The terminology of the Caspicosa male palp morphology follows Kronestedt \& Marusik, [2011], with minor changes; that of the epigyne morphology — Marusik et al. [2004].

The following abbreviations are used in the present article: Eyes: $A L E$ - anterior lateral eye, $A M E$ - anterior median eye, $P L E$ - posterior lateral eye, PME - posterior median eye. PALP: $E$ - embolus, $M A$ - median apophysis (=tegular apophysis), $P$ - palea, $C$ - conductor, $T A-$ terminal apophysis (= paleal apophysis or paleal outgrowth, sensu Marusik et al., 2004), Se - synembolus. LeG CHAETOTAXY: $a$ - apical, $d$ - dorsal, $p l$ - prolateral, $r l$ - retrolateral, $v$ - ventral, spine form as proximal-middle-distal.

The distribution map was produced by means of the online mapping software SimpleMappr [Shorthouse, 2010], with slight modifications.

\section{Genus Caspicosa Ponomarev, 2007}

TYPE SPECIES. Caspicosa manytchensis Ponomarev, 2007 , by the original description.

ETYMOLOGY. The generic name consists of two parts: 'Caspi', referring to the name of the Caspian region, and the second half of the generic name 'Lycosa', which is often used to form generic names in the wolf spiders. Gender: feminine.

DIAGNOSIS AND AFFINITIES. Caspicosa species are similar to some species of the genus Acantholycosa, which are characterized by the none-reduced apical arm of the median apophysis in males. Acantholycosa species were classified by Marusik et al. [2004] in three groups: (1) the khakassica species group (A. khakassica Marusik, Azarkina et Koponen, 2004 and A. petrophila Marusik, Azarkina et Koponen, 2004 from Khakassia, South Siberia; both species are known from males only), (2) the oligerae species group (A. oligerae Marusik, Azarkina et Koponen, $2004\left(\bigcirc^{7}+\right)$ and A. sundukovi Marusik, Azarkina et Koponen, $2004\left(\sigma^{\top}\right)$ from Maritime Territory), and (3) the plumalis species group (A. plumalis Marusik, Azarkina et Koponen, $2004\left(\sigma^{7}+\right)$ and A. paraplumalis Marusik, Azarkina et Koponen, $2004\left(\sigma_{+}^{7}\right)^{\prime}$ from the Altai, South Siberia). Two species remain ungrouped: the Euro-Siberian A. norvegica (Thorell, 1872) $\left(\bigcirc^{7}+\right)$ and the Altaian A. logunovi Marusik, Azarkina et Koponen, $2004\left(\sigma^{7}\right)$. Besides the similarity of the median apophysis, all Caspicosa and the aforementioned Acantholycosa species share at least five common characters: (1) the modified palea with a terminal apophysis in Caspicosa, or a paleal outgrowth in Acantholycosa, (2) the more or less flat lamellar embolus, (3) the longitudinal epigyne consisting of the upper part and fovea, (4) the flat upper part of epigyne, (5) the absence of septum traces in the apical part of the epigyne. Nonetheless, all Caspicosa species can be readily distinguished from those of Acantholycosa by a combination of the following characters (Table 1): (1) two pairs of spines on tibia I (excluding apical spines), (2) the terminal apophysis as a large sharply separated plate, (3) the rounded apical arm of median apophysis, (4) the synembolus present, (5) the apical pocket of epigyne with two distinct hoods, (6) the well-marked, recurved anterior rim of the fovea. Additionally, it is worth noticing that all Caspicosa species are smaller, with shorter legs (see Table 1 for further details).

The Caspicosa species are also similar to members of some Pardosa species groups, viz. the falcata, tesquorum and wagleri species groups as defined by Zyuzin [1979], in particular, by the presence of a large apical shoulder of median apophysis and other characters of the male palp. At the same time, these Pardosa groups significantly differ from Caspicosa in the conformation of the epigyne. Diagnostic characters of the three most similar species-groups of the genus Pardosa are shown in Table 2.

The only Pardosa species - Pardosa vittata (Keyserling, 1863) - has the epigyne being similar to that of the Caspicosa species. P. vittata was assigned to the vittata species group by Zyuzin [1979]. Males of this group differs from those of Caspicosa in the structure of the male palp: (1) the palea with a strongly sclerotized lamellar ridge ('terminal process of shield' in Tongiorgi [1966: fig. 1], "Grat $g$ der Apex" in Thaler [1987: figs 2-4]), (2) the Pardosa 'terminal apophysis' membranous, with two arms ('conductor' and 'terminal apophysis of conductor' in Tongiorgi [1966: fig. 1], 'Konduktor' and 'Terminalapophyse' in Thaler [1987: figs 3, 4]), (3) the embolus simple, round in crosssection [Thaler, 1987: fig. 4]. On the other hand, the female of $P$. vittata has the fovea with lateral lips and anterior rim, as well as the anchor-shaped septum as in the Caspicosa females. However, P. vittata reliably differs from them by the structure of the upper part of the epigyne: the anterior part of septum, anterior lateral lips and the presence of an undivided pocket in the upper part of the epigyne [Tongiorgi, 1966: fig. 2; Thaler, 1987: fig. 1].

DESCRIPTION. Medium size: $\sigma^{7} \sigma^{7}-5.7$ to $6.0 \mathrm{~mm}$ and + + - 6.0 to $8.0 \mathrm{~mm}$ in length. Sexes are alike, with a poorly marked colour sexual dimorphism $\left(\sigma^{\top} \sigma^{7}\right.$ darker, marginal light bands on carapace absent in C. manytchensis or weakly expressed in C. kulsaryensis). Carapace brown, with a light median stripe and narrow marginal bands, that more distinct in females (Figs 4,10). A median band transversely widens behind eyes of the posterior row (Figs 4, 10). The anterior eye row straight, shorter than the median one (Figs $3,6,12)$. AME larger than ALE. Chelicerae dark brown in males (Figs 3, 9), light brown to yellow in females (Figs 6, 12 ), with two promarginal and three retromarginal teeth. Sternum dark (brown or grey) (Figs 2, 8); rarely with a yellowish median spot in females (Fig. 5). Legs yellow; femora with dark sports, basally blackened in males (Figs 1, 3). Tibia I with two pairs of ventral setae (apart from the pair of apical setae). Male abdomen black or dark brown (Figs 1, $2,7,8)$, that one of female grey, with dark spots and with a lighter lanceolate stripe dorsally (Figs 4, 10), grey-yellow ventrally (Figs 5, 11).

Male palp: cymbium with a distal claw, densely covered with bristles (Figs 22, 25, 26); subtegulum in retrolateralproximal position (Fig. 31); the embolic base situated apical-medially on bulbus (Figs 22, 25, 31, 35); the embolus laterally-transverse, narrow and undulant in the dorso-ventral direction (Figs 23, 27, 32, 35); synembolus laminar pinnate in C. manytchensis (Fig. 30, 33) and grooved in $C$. kulsaryensis (Fig. 35), being a functional conductor; conductor as a small membrane (Fig. 32); large, chitinized, more or less rectangular terminal apophysis (Figs 23, 28, 36, $34)$; median apophysis with two arms: large broad apical and small hooked basal ones (Figs 22-24, 25-28, 31).

Female epigyne: epigyne longitudinal, consists of the flat upper part (FAP) and fovea (Fig. 19); FAP width with the anterior stem separating a paired pocket (Figs 19); fovea with distinct lateral lips and anterior rim; septum with a transversal posterior plate and narrow stem (Figs 13-15, 19-20); receptacles oval or elongate, their ducts subequal with the receptaculum length (Fig. 16-18, 21). 
Table 1. Diagnostic characters of Caspicosa species (given in bold) as compared to some species group and species of the genus Acantholycosa.

Таблица 1. Диагностические признаки видов Caspicosa (даны полужирынм) в сравнении с некоторыми группами видов и видами рода Acantholycosa.

\begin{tabular}{|c|c|c|c|c|c|c|c|}
\hline \multirow[b]{2}{*}{ Characteristics } & \multicolumn{2}{|c|}{ Caspicosa } & \multicolumn{5}{|c|}{ Acantholycosa } \\
\hline & $\begin{array}{l}\text { manytchen- } \\
\text { sis }\end{array}$ & $\begin{array}{l}\text { kulsaruen- } \\
\text { sis }\end{array}$ & $\begin{array}{l}\text { khakasica } \\
\text {-group }\end{array}$ & $\begin{array}{l}\text { oligerae- } \\
\text { group }\end{array}$ & $\begin{array}{l}\text { plumalis- } \\
\text { group }\end{array}$ & norvegica & logunovi \\
\hline $\begin{array}{l}\text { Carapace length } \\
\text { (male/female) }\end{array}$ & $\begin{array}{l}2.6-2.9 \\
2.5-2.9\end{array}$ & $\begin{array}{c}3.0 \\
3.4-3.8\end{array}$ & $\begin{array}{c}3.7-4.2 \\
-\end{array}$ & $\begin{array}{l}3.3-4.0 \\
4.3-4.4\end{array}$ & $\begin{array}{l}4.0-4.8 \\
4.3-4.8\end{array}$ & $\begin{array}{l}3.4-4.2 \\
3.6-4.6\end{array}$ & $\begin{array}{c}3.6-3.8 \\
-\end{array}$ \\
\hline $\begin{array}{l}\text { Carapace width } \\
\text { (male/female) }\end{array}$ & $\begin{array}{l}2.0-2.2 \\
2.0-2.3\end{array}$ & $\begin{array}{c}2.2 \\
2.6-2.7\end{array}$ & $\begin{array}{c}2.9-3.3 \\
- \\
\end{array}$ & $\begin{array}{l}2.4-3.1 \\
3.2-3.3 \\
\end{array}$ & $\begin{array}{l}3.2-4.0 \\
3.5-4.1 \\
\end{array}$ & ? & $\begin{array}{c}2.9-3.0 \\
\quad- \\
\end{array}$ \\
\hline $\begin{array}{l}\text { Carapace/Femur I } \\
\text { length (male/female) }\end{array}$ & $\begin{array}{l}1.43-1.49 \\
1.32-1.36\end{array}$ & $\begin{array}{l}1.46 \\
1.23 \\
\end{array}$ & $\begin{array}{c}0.86-0.87 \\
- \\
\end{array}$ & $\begin{array}{c}1.02-1.04 \\
1.18\end{array}$ & $\begin{array}{l}1.02-1.06 \\
1.06-1.13\end{array}$ & $?$ & $\begin{array}{c}1.00 \\
-\end{array}$ \\
\hline $\begin{array}{l}\text { Number of paired } \\
\text { ventral spines on } \\
\text { tibia I (male) }\end{array}$ & 2 & 2 & 5 & $5-6$ & 5 & 5 & 5 \\
\hline Subtegulum position & $\begin{array}{l}\text { retrolateral- } \\
\text { proximal }\end{array}$ & $\begin{array}{l}\text { retrolateral- } \\
\text { proximal }\end{array}$ & proximal & proximal & proximal & proximal & $\begin{array}{l}\text { retrolateral } \\
\text {-proximal }\end{array}$ \\
\hline Embolic shape & $\begin{array}{l}\text { lamellar, } \\
\text { sinuated }\end{array}$ & $\begin{array}{l}\text { lamellar, } \\
\text { sinuated }\end{array}$ & $\begin{array}{l}\text { thin, } \\
\text { straight }\end{array}$ & $\begin{array}{c}\text { lamellar, } \\
\text { turned }\end{array}$ & lamellar & lamellar & $\begin{array}{c}\text { thin, } \\
\text { straight }\end{array}$ \\
\hline Embolic tooth & absent & absent & $\begin{array}{l}\text { bifurcate } \\
\text { spine-like }\end{array}$ & absent & $\begin{array}{c}\text { large } \\
\text { triangle }\end{array}$ & $\begin{array}{c}\text { large } \\
\text { spine-like }\end{array}$ & $\begin{array}{c}\text { small } \\
\text { spine-like }\end{array}$ \\
\hline Embolic tip & rounded & $\begin{array}{l}\text { with lateral } \\
\text { projection }\end{array}$ & $\begin{array}{c}\text { thin } \\
\text { spine-like }\end{array}$ & $\begin{array}{l}\text { wide, } \\
\text { turned }\end{array}$ & $\begin{array}{c}\text { obliquely } \\
\text { cut }\end{array}$ & wide & rounded \\
\hline Terminal apophysis & $\begin{array}{c}\text { large } \\
\text { sharply } \\
\text { separated } \\
\text { plate } \\
\end{array}$ & $\begin{array}{c}\text { large } \\
\text { sharply } \\
\text { separated } \\
\text { plate } \\
\end{array}$ & claw-like & plate-like & claw-like & $\begin{array}{c}\text { small } \\
\text { plate-like }\end{array}$ & claw-like \\
\hline Apical arm of MA & big broad & big broad & $\begin{array}{c}\text { small } \\
\text { triangle } \\
\text { or big } \\
\text { claw-like }\end{array}$ & $\begin{array}{l}\text { big or very } \\
\text { big claw- } \\
\text { like }\end{array}$ & $\begin{array}{l}\text { small } \\
\text { triangle }\end{array}$ & $\begin{array}{l}\text { small } \\
\text { triangle }\end{array}$ & $\begin{array}{l}\text { small spine } \\
\text { shaped }\end{array}$ \\
\hline $\begin{array}{l}\text { Pardosa 'terminal } \\
\text { apophysis' }\end{array}$ & absent & absent & $\begin{array}{c}\text { with } \\
\text { small } \\
\text { spine-like } \\
\text { tip }\end{array}$ & $\begin{array}{c}\text { with } \\
\text { massive } \\
\text { claw-like } \\
\text { tip }\end{array}$ & $\begin{array}{l}\text { small with } \\
\text { spine-like } \\
\text { tip }\end{array}$ & $\begin{array}{c}\text { with } \\
\text { excision } \\
\text { tip and } \\
\text { spine-like } \\
\text { lateral } \\
\text { apophysis }\end{array}$ & $\begin{array}{l}\text { with spine- } \\
\text { like tip }\end{array}$ \\
\hline $\begin{array}{l}\text { Apical pocket of } \\
\text { epigyne }\end{array}$ & paired & paired & - & $\begin{array}{l}\text { one broad } \\
\text { hood }\end{array}$ & one hood & one hood & - \\
\hline $\begin{array}{l}\text { Apical half of septal } \\
\text { stem }\end{array}$ & absent & absent & - & invisible & absent & invisible & - \\
\hline Apical lips & absent & absent & - & absent & $\begin{array}{c}\text { present/ } \\
\text { absent }\end{array}$ & invisible & - \\
\hline Septum shape & anchor & anchor & - & rectangular & T-shaped & $\begin{array}{l}\text { in form of } \\
\text { vase }\end{array}$ & - \\
\hline Anterior rim of fovea & recurved & recurved & - & $\begin{array}{l}\text { procurved, } \\
\text { V-shaped }\end{array}$ & $\begin{array}{l}\text { procurved, } \\
\text { V-shaped }\end{array}$ & procurved & - \\
\hline Receptacula head & oval & elongate & - & elongate & elongate & elongate & - \\
\hline
\end{tabular}

COMPOSITION. Caspicosa chahraka (Roewer, 1960) comb.n., C. kulsaryensis Ponomarev, 2007 and C. manytchensis Ponomarev, 2007.

DISTRIBUTION. The Eastern Ancient Mediterranean (Fig. 38): from the Cis-Caucasia to the Cis-Urals, southward to central highlands of Afghanistan.

\section{Caspicosa chahraka (Roewer, 1960) comb.n.}

Pardosa chahraka Roewer, 1960, 10, fig. 7a-b ( + ).

DIAGNOSIS. By the structure of the epigyne, body size and coloration, the female of $C$. chahraka is very close to that of $C$. manytchensis. Both species are characterized by the epigyne with the anchor-shaped septum and lateral lips in the posterior position, total length 6.5 in C. chahraka and 6.6 (on average) in C. manytchensis, brown carapace with a light median band and lateral margins, and dorsally blackish and ventrally yellowish abdomen. However, Roewer [1960] notes that the chelicerae of $C$. chahraka with three retromarginal teeth only, whereas those of $C$. manytchensis with two promarginal and three retromarginal teeth. Finally, tibiae III and IV with one dorsal seta in C. chahraka, and $1+1$ dorsal setae in $C$. manytchensis. 
Table 2. Diagnostic characters of three species groups of the genus Pardosa by which they differ from the genus Caspicosa. Таблица 2. Диагностические признаки трех групп видов рода Pardosa, по которым они отличаются от рода Caspicosa.

\begin{tabular}{|l|l|l|}
\hline $\begin{array}{l}\text { Pardosa } \text { species } \\
\text { group }\end{array}$ & \multicolumn{1}{|c|}{ Male palp } & \multicolumn{1}{|c|}{ References } \\
\hline falcata & $\begin{array}{l}\text { chitinised palea in its terminal part; embolic base } \\
\text { subdivided by a furrow in two parts; Pardosa 'terminal } \\
\text { apophysis' subdivided in two parts }\end{array}$ & Marusik et al., 2003 \\
\hline tesquorum & $\begin{array}{l}\text { palea with a more or less heavily built basal process; } \\
\text { complex conductor present }\end{array}$ & $\begin{array}{l}\text { Kronestedt, Marusik, } \\
2011\end{array}$ \\
\hline wagleri & $\begin{array}{l}\text { palea with triangular outgrowth or two fine ridges, Pardosa } \\
\text { 'terminal apophysis' with two arms, embolus straight, } \\
\text { conductor with spines on its tip }\end{array}$ & Marusik et al., 2013 \\
\hline
\end{tabular}

DESCRIPTION. See Roewer [1960: 10].

REMARKS. C. chahraka was described from the holotype female collected from the steppe in "Qual"eh Chahrak" of Afghanistan [Roewer, 1960: sub Pardosa c.]. We have found the same geographical name in Theowald's paper, where the locality was described as "Hézeradjat, Qal"eh Chahrak (110 km östl. Kabul)" [Theowald, 1978: 73]. Thus, the type locality of C. chahraka is situated in Hazaristan (or Hazarajat), a mountainous region in the central highlands of Afghanistan (Fig. 38).

Zyuzin [1979] placed P. chahraka into the turkestanica species group with a question mark. In our opinion, based on the conformation of the epigyne, this species is better placed in the genus Caspicosa.

\section{Caspicosa kulsaryensis Ponomarev, 2007}

Figs 1-6, 20-24, 35-37.

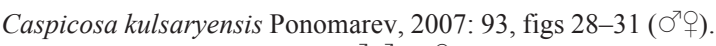
MATERIAL. Kazakhstan: $2 O^{7} \sigma^{7}, 1$ (Paratypes; PC: 25.10 . 33/1), Atyrau Area, Zhylyoi Distr., c. 80 km NNE Kulsary Vil. (47. $\left.5024^{\circ} \mathrm{N}, 54.2780^{\circ} \mathrm{E}\right), 5 . \mathrm{VII} .1987, \mathrm{~V}$. Romanov.

DIAGNOSIS. C. kulsaryensis differs from its congeners by the larger size (e.g., total + length: 7.4-8.0 in C. kulsaryensis, vs. 6.5 in C. chahraka and 6.0-7.0 in C. manytchensis), the T-shaped septum of the epigyne (anchor-shaped in C. chahraka and C. manytchensis; cf. Figs 20 and 13-15), the grooved synembolus (pinnate in C. manytchensis; cf. Figs 35, 37 and 32, 33), and the rounded terminal apophysis (pelecoid in C. manytchensis; cf. Figs 36 and 34).

DESCRIPTION. See Ponomarev [2007: 93].

Male palp: palea reduced, visible in the retrolateral half of bulbus only (Figs 22, 23, 35); embolus narrow, slightly undulant in the antero-posterior direction (Figs 23, 24, 35); embolic tip with a lateral projection (Fig. 37); grooved synembolus curved and rounded on its tip (Figs 35, 37); median apophysis with two arms: large broad apical and small hooked basal ones (Figs 22-24); terminal apophysis with a rounded rim (Fig. 36).

Epigyne: fovea slightly transverse, with lateral lips in the median position (Fig 20); septum transverse, T-shaped; posterior plate with rounded lateral edges (Fig. 20); fovea bottom wrinkled; receptacles elongate; receptacle stem extends along fovea edge (Fig. 21).

DISTRIBUTION. Only the type locality (Fig. 38) [Ponomarev, 2007].
Caspicosa manytchensis Ponomarev, 2007

Figs 7-19, 25-34. $\left.\left(O^{T}+\right)^{C}\right)$

Caspicosa manytchensis Ponomarev, 2007: 93, figs 24-27

MATERIAL. Russia: $14 \mathrm{O}^{7} \mathrm{O}^{7}, 2$ 우 (Paratypes; PC: 25.10.34/ 8), Rostov Area, Orlovskiy District, Rostovskiy Nature Reserve, flood land of Manych River $\left(46.4116^{\circ} \mathrm{N}, 427077^{\circ} \mathrm{E}\right)$, Artemisia steppe, 6-7.V.2004, A.V. Shimko; $10^{7}$ (PC: 25.10.34/10), same area and distr., Manych Vil., shore of Lake Manych-Gudilo, saline land, 18.V.2008, A.V. Ponomarev; 1 O$^{7}$ (PC: 25.10.34/11), same area and distr., Manych Vil., Manych-Gudilo Lake, Vodniy Island, saline land, 30.IV.2016, E.A. Eremenko; $71 \sigma^{7} \sigma^{7}, 53$ OQ (PC: 25.10.34/12), same locality and biotope, 24.VI-6.VIII.2016, E.A. Eremenko; 11 우 (PC: 25.10.34/13), same locality and biotope, 19.VIII-16.IX.2016, E.A. Eremenko; 1 (PSU-5500), Orenburg Area, c. $2 \mathrm{~km} \mathrm{SE}$ of Sol'-Iletsk Town, sandy banks of Elshanka River, pitfall-traps, 10-17.V.2008, V.O. Koz'minykh; 1 \& (PSU6489), same area, Svetliy Distr., c. $12 \mathrm{~km} \mathrm{~S}$ of Yasniy Vil., steppe, 7.V.2015, S.L. Esyunin; $47 \mathrm{O}^{7} \mathrm{O}^{7}, 10$ 우우 (PSU-8701), $5 \mathrm{O}^{2} \mathrm{O}^{2}, 2$ 우우 (MMUE), $15 \sigma^{7} O^{7}, 5$ OQ (ZMMU), Talovskaya Steppe division of the Orenburg Reserve $\left(51^{\circ} 47^{\prime} \mathrm{N}, 50^{\circ} 52^{\prime} \mathrm{E}\right)$, Artemisia and FestucaArtemisia steppes, saline land, pitfall-traps, 30.IV-7.V.2019, S.L. Esyunin.

DIAGNOSIS. See above under 'Diagnosis' of C. kulsaryensis.

DESCRIPTION. MALE. Measurements. Total length 5.45 (5.00-5.75). Carapace 2.75 (2.60-2.85) long, 2.04 (2.00-2.15) wide; width/length ratio $0.74(0.70-0.77)$. Clypeal height $0.17(0.15-0.20)$, one and a half times AME diameter. Anterior eye row $0.56(0.55-0.60)$ wide; median eye row $0.78(0.75-0.80)$ wide, posterior eye row 1.11 (1.081.13 ) wide; ocular area (formed by median and posterior yeas) $0.73(0.71-0.76)$ long. Eye sizes: AME 0.10, ALE 0.08, PME 0.26, PLE 0.24. AME-AME distance 0.10; AMEALE distance 0.05 . Chelicera 1.03 (1.00-1.05) long. Abdomen 2.70 (2.4-2.9) long. Leg formula: IV, I, II, III. Leg measurements are given in Table 3.

Leg spination: Femur I d 1-1-1, pl 0-0-1(2), rl 0-1-1; II and III d 1-1-1, pl 0-1-1, rl 0-1-1; IV d 1-1-1, pl 0-1-1, rl 0$0-1$; Tibia I and II pl 1-1-0, rl 0-1-1, v 2-2-2a; III d 1-1-0, pl 1-1-0, rl 1-0-1, v 2-2-2a; IV d 1-1-1, pl 1-0-1, rl 1-0-1, v 22-2a; Metatarsi I-IV pl 1-1-1, rl 1-1-1, v 2-2-3a.

Coloration: Carapace dark brown, darker around its margins; thoracic part with gray curved radial lines; ocular area black, covered with white setae; clypeus dark brown (Fig. 9). Chelicerae brown with two promarginal and three retromarginal teeth. Endites yellow; labium grey-brown with greyyellow apexes. Sternum dark brown, covered with white hairs. Palps brown, cymbium black. Legs yellow; apical part of femur dark brown. Tarsi and metatarsi without scopulae. 


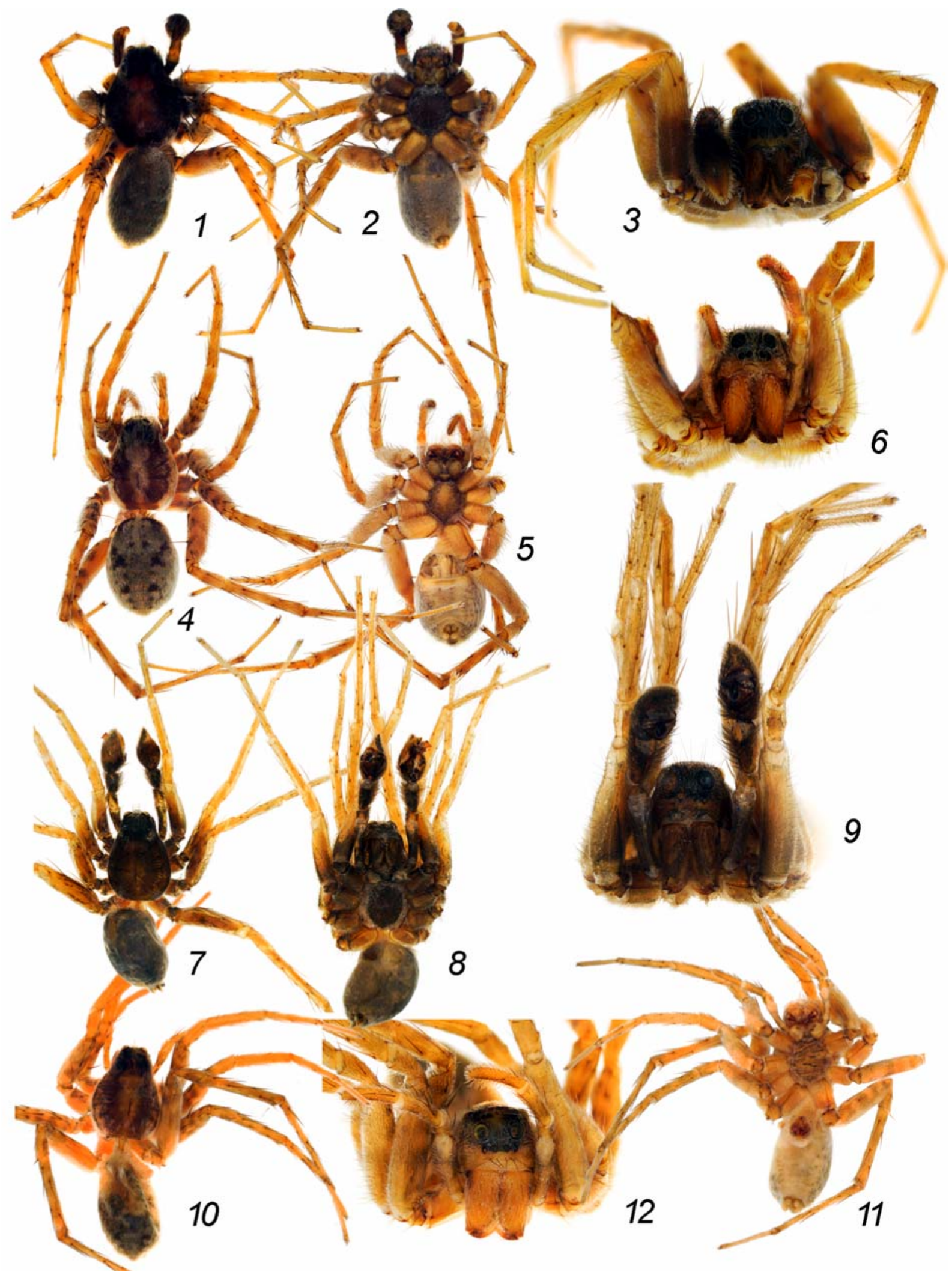

Figs 1-12. General appearance of Caspicosa kulsaryensis Ponomarev, 2007 (1-6, paratypes) and C. manytchensis Ponomarev, 2007 (7-12, paratypes): 1-3, 7-9 - male, 4-6, 10-12 - female.

Рис. 1-12. Общий вид Caspicosa kulsaryensis Ponomarev, 2007 (1-6, паратипы) и C. manytchensis Ponomarev, 2007 (7-12, паратипы), общий вид: 1-3, 7-9- самец, 4-6, 10-12 - самка. 

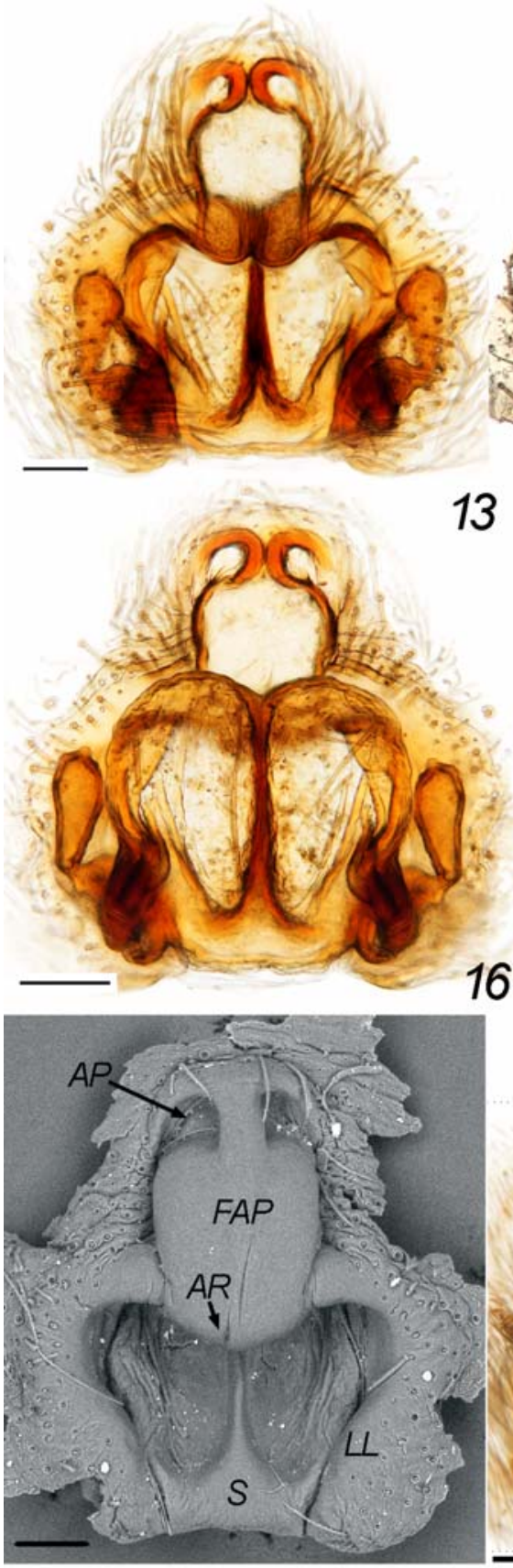

19

16

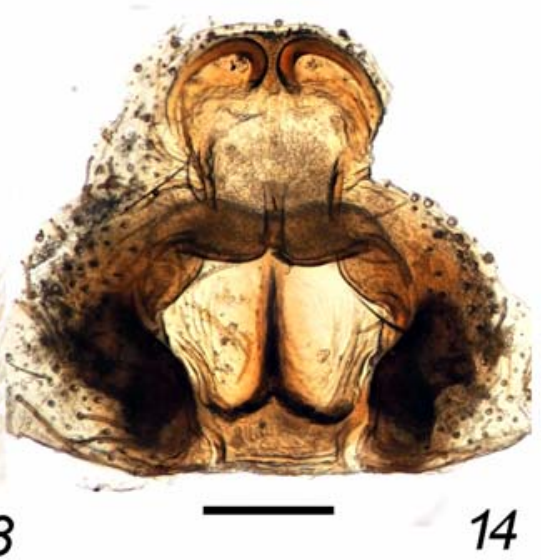

14

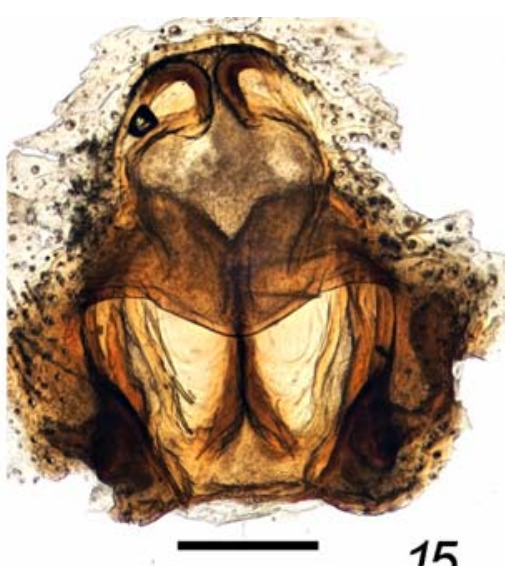

15

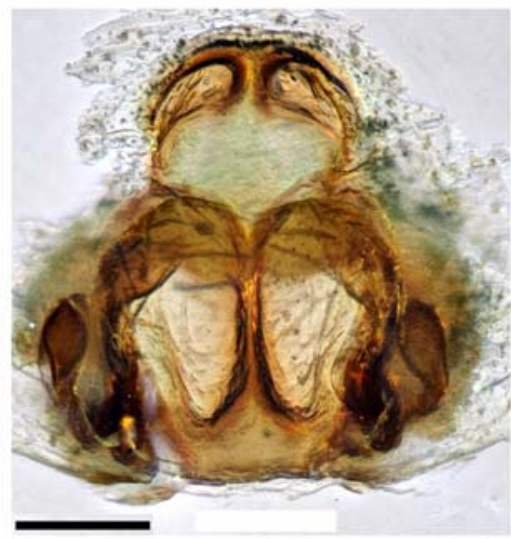

17

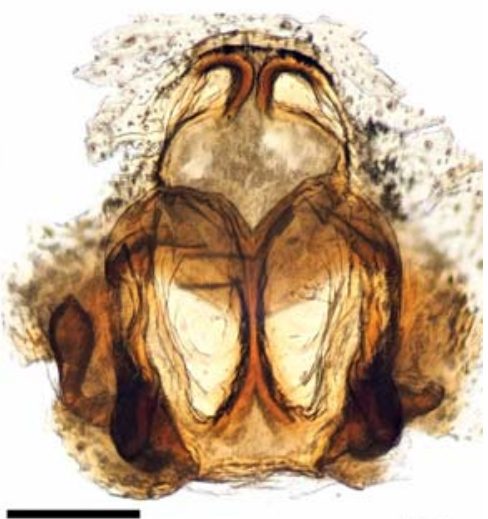

18

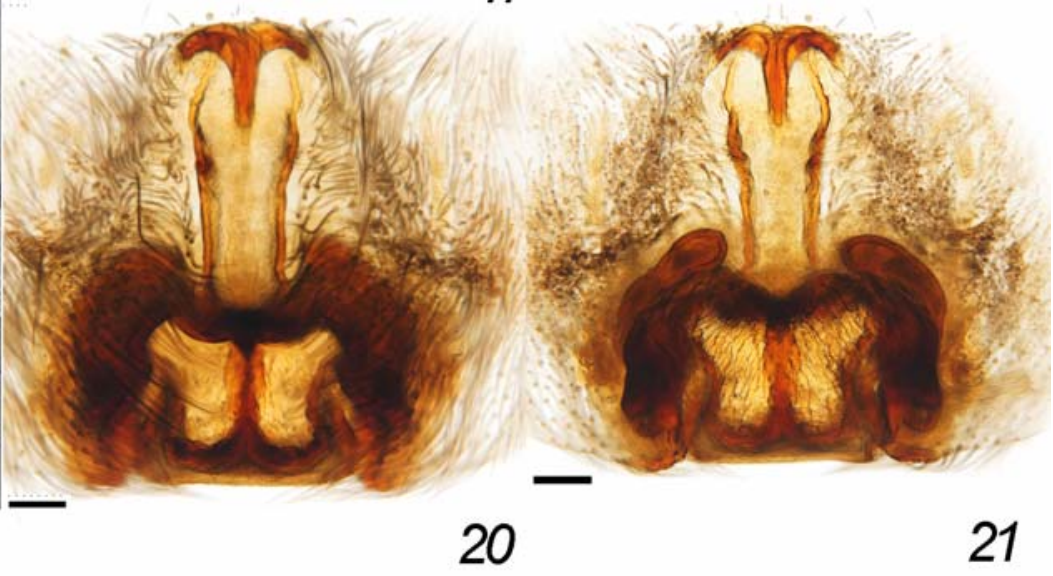

Figs 13-21. Epigyne (13-15, 19, 20) and endogyne (16-18, 21) of Caspicosa kulsaryensis Ponomarev, 2007 (20, 21 , paratypes) and C. manytchensis Ponomarev, 2007 (13, 16 - paratypes; 14, 15, 17-19 — Orenburg Area). Scale bars: 0.1 mm. Abbreviations: AP anterior pocket, AR — anterior rim of fovea, FAP — flat upper part of epigyne, LL — lateral lips, S — septum.

Рис. 13-21. Эпигина $(13-15,19,20)$ и эндогина $(16-18,21)$ Caspicosa kulsaryensis Ponomarev, 2007 (20, 21, паратипы) и C. manytchensis Ponomarev, 2007 (13, 16 - паратипы; 14, 15, 17-19 - Оренбургская обл.). Масштаб: 0,1 мм. Сокращения: AP — передние карманы, AR - передний край ямки, FAP — плоская передняя часть эпигины, LL — боковые губы, S — септум.

Abdomen (Figs 1, 2): black with a lanceolate light brown spot and with numerous grey dots forming more or less pronounced rows; venter grey, covered with white hears.

Male palp: cymbium densely covered with bristles and with a distal apical claw (Figs 25, 26); palea not modified (Figs 25, 27, 31); embolus wide, angularly curved in the dorso-ventral direction, with bristles at its bend (Figs 29,
$33)$, and narrow undulant in the antero-posterior direction (Figs 27, 32); embolic tip rounded (Fig. 29); synembolus laminar-pinnate (Figs 30, 32, 33); median apophysis plateshape, with two bent arms: large broad apical and small hooked basal (Figs 24, 26, 28, 31); pelecoid terminal apophysis with a straight rim (Fig. 34); conductor small, membranous (Fig. 32). 

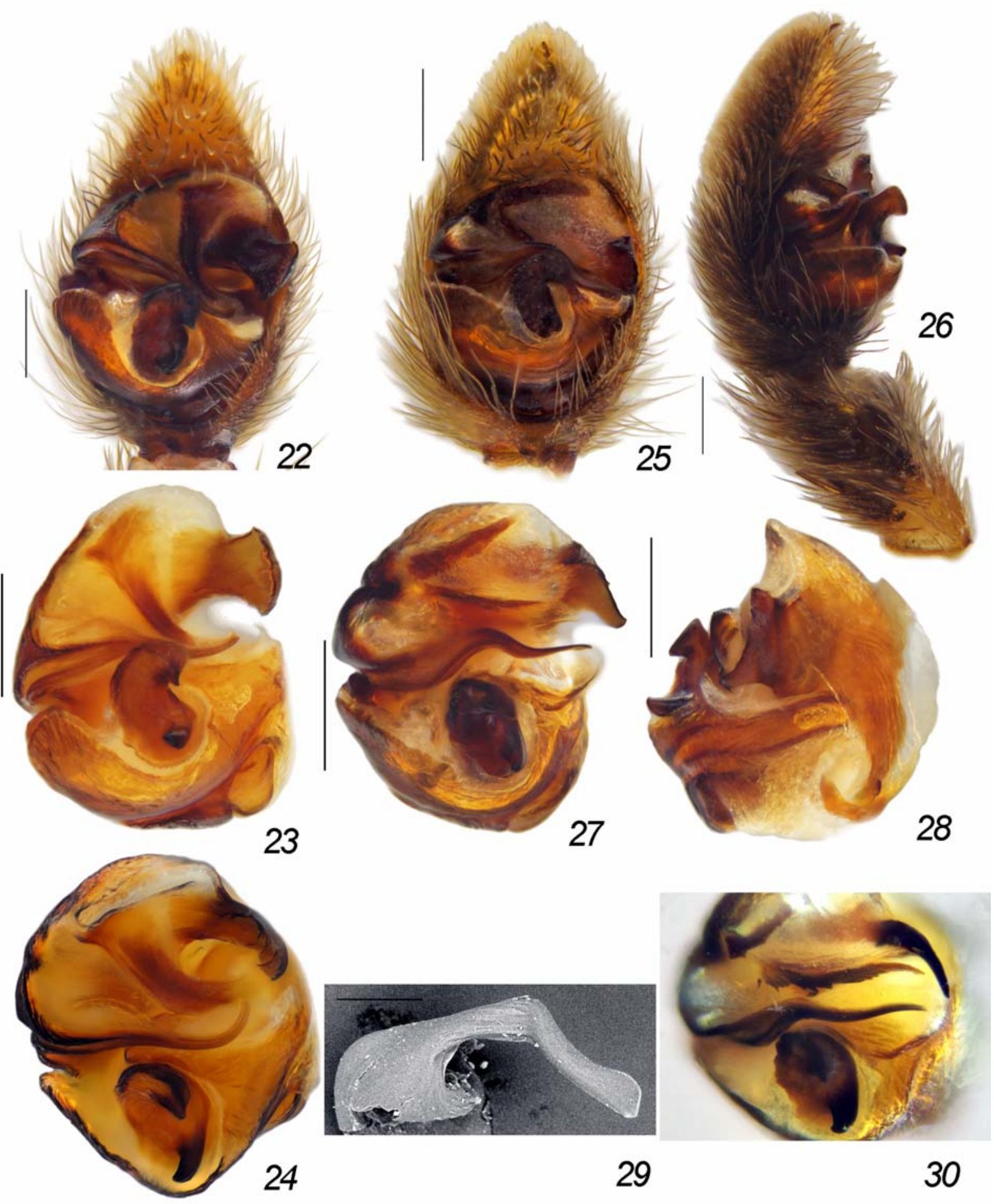

Figs 22-30. Male palp of Caspicosa kulsaryensis Ponomarev, 2007 (22-24, paratypes) and C. manytchensis Ponomarev, 2007 (25-28 - paratypes; 29, 30 - Orenburg Area): 22, 25 - palp, ventral view, 26 - same, lateral view; 23, 24, 27, 28, 30 - bulbus, ventro-apical $(23,27)$, apical $(24,30)$ and retrolateral $(28)$ view; 29 - embolus, apical view. Scale: $0.1 \mathrm{~mm}$.

Рис. 22-30. Пальпа самца Caspicosa kulsaryensis Ponomarev, 2007 (22-24, паратипы) и C. manytchensis Ponomarev, 2007 (25-28 - паратипы; 29, 30 - Оренбургская обл.): 22, 25 - пальпа, вентрально, 26 - то же, сбоку; 23, 24, 27, 28, 30 - бульбус, снизу-спереди $(23,27)$, спереди $(24,30)$ и сбоку $(28) ; 29$ - эмболюс, спереди. Масштаб: 0,1 мм. 


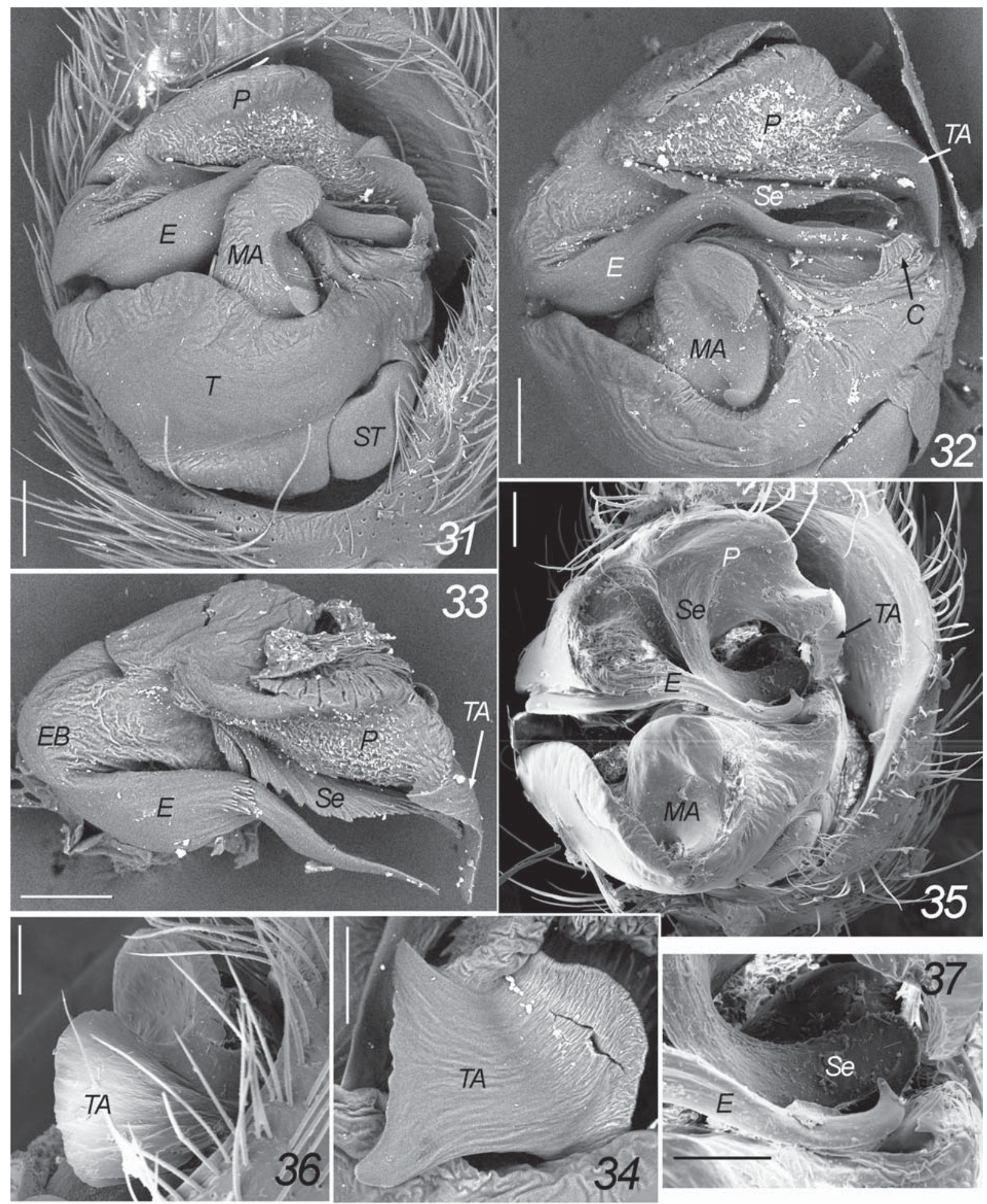

Figs 31-37. SEM micrographs of the male palp of Caspicosa kulsaryensis Ponomarev, 2007 (35-37, paratypes) and C. manytchensis Ponomarev, 2007 (31-34, Orenburg Area): 31 - bulbus, ventral view, 32, 35 - same, ventro-apical view; 33 - palea and embolus, apical view; 34, 36 - terminal apophysis, lateral view; 37 - embolus and synembolus tips, ventro-apical view. Scale: $0.1 \mathrm{~mm}$. Abbreviations: $C$ - conductor, $E$ - embolus; $E B$ - base of embolus; $M A$ - median apophysis; $P$ - palea; $S$ - synembolus, $S T$ subtegulum, $T A-$ terminal apophysis.

Рис. 31-37. Сканирующие микрофотографии пальпы самца Caspicosa kulsaryensis Ponomarev, 2007 (35-37, паратипы) и C. manytchensis Ponomarev, 2007 (31-34, Оренбургская обл.): 31 - бульбус, снизу, 32, 35 - тоже, снизу-спереди; 33 - палеа и эмболюс, спереди; 34, 36 - терминальная апофиза, сбоку; 37 - вершины эмболюса и синэмболюса, снизу-спереди. Масштаб: 0,1 мм. Аббревиатура: $C$ - кондуктор, $E$ - эмболюс; $E B$ - основание эмболюса; $M A-$ срединный отросток; $P-$ палеа; $S-$ синэмболюс, $S T$ - субтегулум, $T A$ - терминальный отросток. 


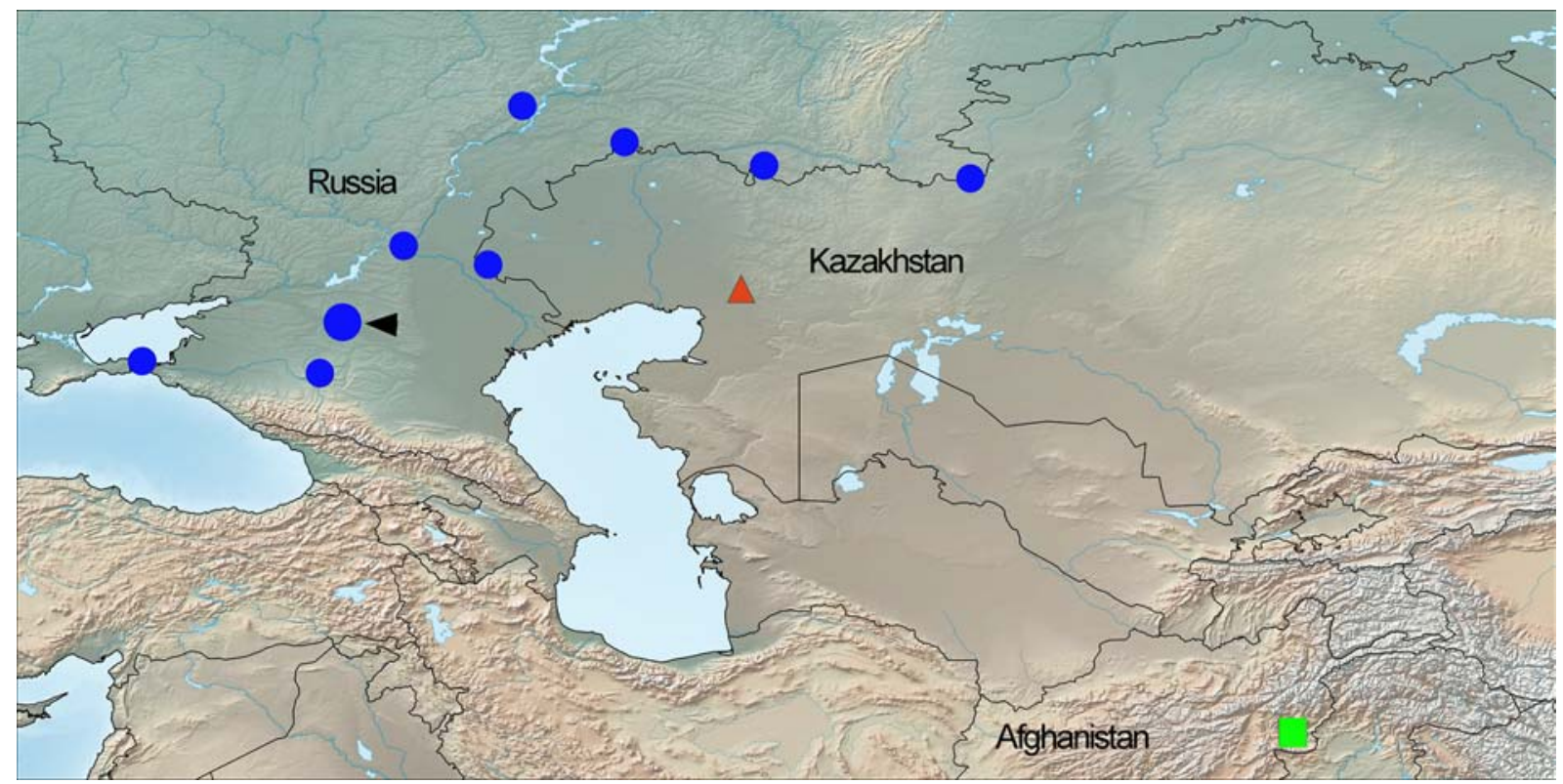

Fig. 38. Distribution of the Caspicosa species: C. chahraka (Roewer, 1960) (square), C. kulsaryensis Ponomarev, 2007 (triangle) and C. manytchensis Ponomarev, 2007 (circle; the type locality is arrowed).

Рис. 38. Распространение видов Caspicosa: C. chahraka (Roewer, 1960) (квадрат), C. kulsaryensis Ponomarev, 2007 (треугольник) и C. manytchensis Ponomarev, 2007 (круг; типовой локалитет показан стрелкой).

Table 3. Length of leg segments in Caspicosa manytchensis Ponomarev, 2007 (average/min-max). Таблица 3. Длина сегментов ног Caspicosa manytchensis Ponomarev, 2007 (среднеe/ min-max).

\begin{tabular}{|l|c|c|c|c|c|}
\hline \multicolumn{1}{|c|}{ Leg } & Femur & Patella+Tibia & Metatarsus & Tarsus & Total length \\
\hline Male & \multicolumn{5}{|c|}{} \\
\hline \multirow{2}{*}{ I } & 1.84 & 2.32 & 1.51 & 1.19 & 6.86 \\
& $1.75-2.00$ & $2.25-2.50$ & $1.35-1.75$ & $1.10-1.30$ & $6.55-7.55$ \\
\hline \multirow{2}{*}{ II } & 1.78 & 2.17 & 1.51 & 1.13 & 6.56 \\
& $1.75-1.85$ & $2.00-2.35$ & $1.45-1.65$ & $1.05-1.20$ & $6.30-7.00$ \\
\hline \multirow{2}{*}{ III } & 1.76 & 2.07 & 1.55 & 1.13 & 6.53 \\
& $1.75-1.80$ & $1.90-2.25$ & $1.45-1.65$ & $1.05-1.20$ & $6.15-7.00$ \\
\hline \multirow{2}{*}{ IV } & 2.31 & 2.74 & 2.59 & 1.40 & 9.04 \\
& $2.25-2.45$ & $2.55-2.95$ & $2.25-2.90$ & $1.25-1.55$ & $8.35-9.85$ \\
\hline Female & 2.00 & 2.50 & 1.48 & 1.10 & 7.08 \\
\multirow{2}{*}{ I } & $1.90-2.10$ & $2.25-2.75$ & $1.35-1.60$ & $1.05-1.15$ & $6.55-7.60$ \\
\hline \multirow{2}{*}{ II } & 1.97 & 2.33 & 1.53 & 1.10 & 6.93 \\
& $1.90-2.00$ & $2.25-2.50$ & $1.50-1.60$ & $1.05-1.15$ & $6.70-7.25$ \\
\hline \multirow{2}{*}{ III } & 1.95 & 2.25 & 1.53 & 1.10 & 6.88 \\
& $1.90-2.00$ & $2.10-2.40$ & $1.45-1.60$ & $1.05-1.15$ & $6.55-7.25$ \\
\hline \multirow{2}{*}{ IV } & 2.53 & 3.20 & 3.00 & 1.35 & 10.08 \\
& $2.35-2.75$ & $3.10-3.25$ & $2.75-3.25$ & $1.30-1.40$ & $9.55-10.55$ \\
\hline
\end{tabular}

FEMALE. Measurements. Total length 6.58 (6.00-7.00). Carapace 2.70 (2.50-2.85) long, $2.12(2.00-2.25)$ wide; width/length ratio $0.78(0.76-0.80)$. Clypeal height 0.18 $(0.15-0.20)$, one and a half times AME diameter. Anterior eye row $0.58(0.58-0.60)$ wide; median eye row $0.86(0.83-$ $0.88)$ wide, posterior eye row $1.11(1.08-1.13)$ wide; ocular area (formed by median and posterior yeas) 0.74 (0.710.76) long. Eye sizes: AME 0.10, ALE 0.08, PME 0.27, PLE 0.24. AME-AME distance 0.10; AME-ALE distance 0.06. Chelicera $1.12(1.10-1.15)$ long. Abdomen 3.88 (3.50-
4.15) long. Leg formula: IV, I, II, III. Leg measurements are given in Table 3.

Leg spination: Femur I d 1-1-1, pl 0-0-2, rl 0-1-1; II and III d 1-1-1, pl 0-1-1, rl 0-1-1; IV d 1-1-1, pl 0(1)-1(0)-1, rl $0-0-1$; Tibia I pl 1-1-0, rl 0(1)-1(0)-1, v 2(4)-2-2a; II pl 1-10 , rl 1(0)-0(1)-1, v 2-2-2a; III d 1-1-0, pl 1-1-0, rl 1(0)-0(1)1, v 2-2-2a; IV d 1-1(0)-0(1), pl 1-0-1, rl 1-0-1, v 2-2-2a; Metatarsi I-IV pl 1-1-1, rl 1-1-1, v 2-2-3a.

Coloration. Carapace yellow-brown; thoracic part with gray curved radial lines; ocular area black covered with 
white setae; clypeus yellow (Fig. 12). Chelicerae yellow, with two promarginal and three retromarginal teeth. Endites yellow; labium grey-yellow, with yellow apexes. Sternum grey-yellow, covered with white hairs. Palps and legs yellow; femur of legs with dorsal indistinct gray transverse stripes. Tarsi and metatarsi without scopulae. Abdomen (Figs $10,11)$ : dorsum black, with a lanceolate grey-brown spot and with numerous yellow dots forming more or less pronounced rows, covered with light hears; venter yellowish white, covered with white hears.

Epigyne: fovea more or less cordate, slightly transverse, with lateral lips in the posterior position (Fig 20); septum anchor-shaped; posterior plate with strait lateral edges (Figs 13-15, 19); endogyne with relatively short receptacles, receptacle stem transverse; receptacle head small, oval (Figs 16-18).

DISTRIBUTION. Russia (Fig. 38): Krasnodar Territory [Ponomarev et al., 2017b, 2018], Rostov Area, Stavropol Territory [Ponomarev, Tsvetkov, 2004: sub Pardosa sp.; Ponomarev, 2007, 2010; Lebedeva et al., 2010; Ponomarev et al., 2017a; Ponomarev, Prishutova, 2017], Astrakhan Area [Ponomarev, Alekseev, 2018], Volgograd Area [Ponomarev, Khnykin, 2013], Ulyanovsk Area [Alekseenko, Kuz'min, 2010], Orenburg Area (present data).

Acknowledgments. We wish to express our gratitude to the following persons for giving access to the material studied in the paper: T.K. Tuneva (Ekaterinburg, Russia) and E.A. Eremenko (Rostov-on-Don, Russia). We are also obliged to V.Yu. Shmatko (Rostov-on-Don, Russia), A.V. Grischenko (Perm, Russia) and N.B. Ovchankova (Perm, Russia) for producing digital photographs and SEM micrographs, respectively. Special thanks go to D.V. Logunov (Manchester, UK) for commenting on the manuscript and for editing the English of the final draft.

This work was partly prepared as the implementation of the state task of the Southern Scientific Centre of the Russian Academy of Sciences (No. AAAA-A19-1190111901767; Ponomarev A.V.).

\section{References}

Alekseenko Yu.G., Kuz'min E.A. 2010. [Notes on the spider fauna of the Ulyanovsk region (Arachnida: Aranei). New faunal records] // Priroda Simbirskogo Povolzh'ya. Vol.11. Ulyanovsk: Izdatel'stvo "Korporatsiya tekhnologiy prodvizheniya". P.99103 [in Russian].

Kronestedt T., Marusik Yu.M. 2011. Studies on species of Holarctic Pardosa groups (Araneae, Lycosidae). VII. The Pardosa tesquorum group // Zootaxa. Vol.3131. P.1-34.

Lebedeva N.V., Ponomarev A.V., Savitskiy R.M., Arzanov Yu.G., Il'ina L.P. 2010. [Terrestrial fauna as an indicator of pasture load] // Vestnik Yuzhnogo nauchnogo tsentra RAN. Vol.6. No.4. P.84-95 [in Russian. with English summary].

Marusik Yu.M., Guseinov E.F., Koponen S. 2003. A survey of east Palaearctic species Lycosidae (Araneae). I. On of the Pardosa falcata-group // Acta Arachnologica. Vol.52. No.1. P.43-50.

Marusik Yu.M., Azarkina G.N., Koponen S. 2004. A survey of east Palearctic Lycosidae (Aranei). II. Genus Acantholycosa F. Dahl,
1908 and related new genera // Arthropoda Selecta. Vol.12 (for 2003). No.2. P.101-148.

Marusik Yu.M., Nadolny A.A., Omelko M.M. 2013. A survey of east Palearctic Lycosidae (Araneae). 10. Three new Pardosa species from the mountains of central Asia // Zootaxa. Vol.3722. P.204-218.

Ponomarev A.V. 2007. New taxa of spiders (Aranei) from the south of Russia and western Kazakhstan // Caucasian Entomological Bulletin. Vol.3. No.2. P.87-95 [in Russian, with English summary].

Ponomarev A.V. 2010. [Spiders (Arachnida: Aranei) of the Rostovskiy Nature Reserve: Cadastre of species and fauna features] // Trudy Gosudarstvennogo prirodnogo zapovednika "Rostovskiy": Monitoring prirodnykh ekosistem doliny Manycha. Rostov-on-Don. Vol.4. P.105-125 [in Russian].

Ponomarev A.V., Alekseev S.K. 2018. [Spring aspect in the ground fauna of spiders (Aranei) of the Bogdinsko-Baskunchaksky Reserve] // Nauka yugha Rossii. Vol.14. No.3. P.101-111 [in Russian, with English summary].

Ponomarev A.V., Alekseev S.K., Kozminykh V.O., Shmatko V.Yu. 2017a. Spiders (Arachnida: Aranei) of Stavropol Province, Russia // Arthropoda Selecta. Vol.26. No.2. P.155-173.

Ponomarev A.V., Khnykin A.S. 2013. [Spiders (Aranei) of Volgograd City and its adjacensis] // Yugh Rossii: ekologyia, razvitie. No.4. P.109-136 [in Russian, with English summary].

Ponomarev A.V., Prishutova Z.G. 2017. [Terrestrial spider (Aranei) of Vodnyi Island (Manych-Gudilo Lake)] // Nauka yugha Rossii. Vol.13. No.2 P.60-65 [in Russian, with English summary]. DOI: 10.23885/2500-0640-2017-13-2-60-65.

Ponomarev A.V., Prokopenko E.V., Shmatko V.Yu. 2017b. [New and interesting records of spiders (Arachnida: Aranei) from the southeastern part of the Russian Plain] // Trudy Russkogo entomologicheskogo obstchestva. Vol.88. No.1. P.103-117 [in Russian, with English summary].

Ponomarev A.V., Shokin I.V., Terskov E.N., Shmatko V.Yu. 2018. [Preliminary data on the fauna of spiders (Aranei) of Taman Peninsula and Tuzla Island (Russia)] // Caucasian Entomological Bulletin. Vol.14. No.2. P.121-129 [in Russian, with English summary].

Ponomarev A.V., Tsvetkov A.S. 2004. [Generalized data on spiders (Aranei) of the Rostovskiy Nature Reserve] // Trudy Gosudarstvennogo prirodnogo zapovednika "Rostovskiy". Vol.3. Rostov-on-Don: Donskoy Publishing House. P.84-104 [in Russian].

Roewer C.F. 1960. Lycosidae aus Afghanistan (Araneae) // Acta Universitatis Lundensis (N.F.) Avd.2. Bd.56. Nr.17. S.1-34.

Shorthouse David P. 2010. SimpleMappr, an online tool to produce publication-quality point maps. Available at http://www. simplemappr.net (accessed August 12, 2017).

Thaler K. 1987. Pardosa vittata (Keyserling) - neu für Österreichund weitere Wolfspinnen aus dem Kulturland des Grazer Beckens (Araneae, Lycosidae) // Sitzungsberichte der Österreichischen Akademie der Wissenschaften. Bd.195. S.191-199.

Theowald B. 1978. Tipuliden aus Iran und Afghanistan (Diptera, Tipulidae) // Bulletin Zoölogisch Museum, Universiteit van Amsterdam. Vol.6. No.10. P.69-77.

Tongiorgi P. 1966. Italian wolf spiders of the genus Pardosa (Araneae: Lycosidae) // Bulletin of the Museum of Comparative Zoology. Vol.134. No.8. P.275-334.

Zyuzin A.A. 1979. A taxonomic study of Palearctic spiders of the genus Pardosa (Aranei, Lycosidae). Part 1. The taxonomic structure of the genus // Entomologicheskoye Obozrenie. Vol.58. No.2. P.431-447 [in Russian].

Responsible editor D.V. Logunov 